\title{
Debris flows and debris floods occurrence in the Ribnishka River watershed (southern slopes of Ograzhden Mountain)
}

\section{Проява на кално-каменни потоци и дебритни прииждания във водосбора на река Рибнишка (южните склонове на Огражден)}

\author{
Zornitsa Dotseva, Dian Vangelov, Ianko Gerdjikov \\ Зорница Доцева, Диан Вангелов, Янко Герджиков
}

Sofia University “St. Kliment Ohridski”, blvd. Tsar Osvoboditel 15, Sofia; E-mail: zdoceva@gea.uni-sofia.bg

\begin{abstract}
The Ribnishka River watershed, located on the southern slopes of Ograzhden Mountain is known for the repeated torrential events in the last few decades. In this paper, we represent a preliminary assessment of the debris floods and debris flows hazard in the Ribnishka River watershed. For this purpose, the topographic conditions in the watershed are considered, the source, transport, and deposition zones are characterized, as well as the observed sediment deposits in the river valley. The obtained results could be used in the development of risk management plans, but also provide new information on the development of debris floods and debris flows in this part of the country.
\end{abstract}

Keywords: debris flows, debris floods, natural hazards, Ograzhden Mountain.

Кално-каменните потоци и дебритните прииждания са процеси, които се проявяват в планински райони и играят голяма роля за седиментния транспорт. Разликата между тях се изразява във водното съдържание, което оказва влияние върху типа на потока. За практически цели тези два типа процеси се разграничават основно поради различните мерки за превенция, които се прилагат. Те могат да се развиват едновременно в рамките на един басейн, но се различават в геоморфоложките, реоложките и седиментоложките им характеристики. Като основен задвижващ фактор за процесите се определят интензивните валежи, но сыщо така топографските и геоложките условия на района, които оказват силно влияние за формирането и развитието им.

В южните склонове на Огражден водосборите, разположени северно и западно от с. Първомай (р. Рибнишка, р. Градешница), многократно са били под влиянието на поройни явления с различен интензитет в последните десетилетия, причинявайки щети за близко разположената инфраструктура и населените места. За това говорят съвременните отложения в речните долини, както и изградената още преди 40 години система от баражи, които са били неколкократно компро- ментирани и разрушавани в миналото. Едно от добре документираните събития се случва през 2000 г. (Panov, 2000), когато баражите са разрушени (възстановени към 2019 г.), а мостът, който свързва селата Долна Рибница и Мендово със с. Първомай, е изцяло разрушен. По данни от местното население наводнения в с. Долна Рибница е имало и през 2010 и 2013 година.

В настоящия текст е разгледан водосборът на р. Рибнишка, който след преглед на наличната информация - литературни данни, сателитни изображения и теренен анализ, беше определен като водосбор с опасност от проява както на дебритни прииждания, така и на кално-каменни потоци, които са съсредоточени във високите части на водосбора, в зоната на подхранване. За предварителна оценка на опасността е извършен ГИС анализ на релефа и морфометричен анализ на водосбора, като тези анализи са допълнени от теренни данни за установяване на геоложките условия, както и за характеризиране на зоните на подхранване, транспорт и отлагане. Получените данни дават нова информация за проявата на дебритни прииждания и кално-каменни потоци в тази част на България, както и спомагат за по-доброто разбиране на опасните процеси, 
които се развиват в обхвата на водосбора на р. Рибнишка.

Водосборьт на р. Рибнишка, която е ляв приток на р. Струмешница, се разполага северно от с. Пьрвомай, в южните склонове на Огражден. Климатьт се характеризира като преходносредиземноморски, със средната годишна валежна сума от $600 \mathrm{~mm} / \mathrm{y}$, с летен минимум и зимен максимум на валежите. Екстремни стойности на валежите са наблюдавани през пролетните месеци, като с тях се привързват и поройните явления в района.

Релефът се характеризира като силно разчленен ниско- до среднопланински. Максималната надморска височина в изследвания район е 1512 m (фиг. 1a). Площта на водосбора на р. Долна Рибница е $16,4 \mathrm{~km}^{2}$ със средна надморска височина от $765 \mathrm{~m}$ и среден наклон на склона $17,3^{\circ}$. В горните части на водосбора се наблюдават и склонове с наклон над $35^{\circ}$ (фиг. 1б).

Геоложкият строеж в изследвания водосбор е сравнително еднороден, изграден основно от мигматизирани гнайси, част от Огражденския метаморфен комплекс (Klimov et al., 2004). Кватернерни отложения, които се разкриват в някои участъци в речната долина, оформят конуси в основата на склона, изградени от седименти с размер от чакъли до валуни.

За изследвания водосбор са изчислени четири морфометрични индекса - Form Factor (FF - за оценка на формата на водосбора; Horton, 1932); Elevation Relief Ratio (ERR - етап на развитие и ерозионна еволюция на водосбора; Pike et al., 1971); Melton Ruggedness Number (MRN - за определяне на вида на седиментен транспорт; Melton, 1965); Drainage Density (DD - оценка на ерозионната активност и устойчивост във водосбора; Horton, 1932). Получените резултати показват, че формата на водосбора е издължена $(\mathrm{FF}=0,14)$, в сравнително зрял етап на развитие $(\mathrm{ERR}=0,46)$, c умерена ерозионна активност $\left(\mathrm{DD}=2,10 \mathrm{~km} / \mathrm{km}^{2}\right)$, а видът на основния седиментен транспорт може да се категоризира като дебритно прииждане (Wilford et al., 2004) (MRN=0,43).

На базата на долинната морфология и характера на процесите на трансфер на кластичен материал, в долината на р. Рибнишка могат да се отделят зони на подхранване, транспорт и отлагане. С голямо значение за развитието на процесите във водосбора е зоната на подхранване, която се локализира на надморска височина над $600 \mathrm{~m}$. Морфологията на речната долина в тази зона се характеризира със стръмни склонове, на места с наклон до над $35^{\circ}$, покрити частично с горска растителност и интензивно развитие на ерозионни процеси. Единият източник на материал в тази зона са срутванията на скален материал от двата склона на долината, изградени от изветрелите и нестабилни гнайси на Огражденския метаморфен комплекс. От друга страна, повърхностната ерозия по склоновете формира ерозионни структури, даващи началото на „поройни“ кално-каменни потоци (gully debris flows) (фиг. 1в). Ocновен механизъм на задвижване на тези потоци са интензивните валежи и голямата скорост на водния отток в оврази и стрьмни сухи дерета, което причинява ерозия на склоновете и отмиване на ерозиралия материал (Kean et al., 2013). Те се явяват основен източник на седименти, които се натрупват в долината на р. Рибнишка и които, след мобилизиране, могат да бъдат въвлечени в дебритни прииждания, засягащи долното течение на реката. Наблюдават се характерни форми на отложенията - странични диги, напречни валове, както и частично изместване (partial river avulsion) и врязване на постоянния речен канал. Освен това, промяната в посоката на р. Рибнишка оформя своеобразен „капан“ за седиментите и натрупване на големи обеми в този участьк от речната долина (фиг. 1г).

Според теренните данни, основният тип на седиментен транспорт във долината на р. Рибнишка може да се разглежда като дебритно прииждане. Намаляването на наклона в зоната на транспорт, която се разполага в средното и долното течение на водосбора (600-200 т н.в.), води до потенциално понижение на интензитета на потока. В районите на вливане на речните притоци и по бреговете на активния речен канал се натрупва седиментен материал, изграден от заоблени до полузаоблени, несортирани до слабосортирани класти с размер от чакъли до валуни, предимно от гнайси, съсредоточен най-вече около изградените баражи в долното течение на реката. Долинните склонове в тази зона са с наклон около $20^{\circ}$, частично залесени, на места силно ерозирали. Поради понижаването на наклона на склона и изградените баражи, в наши дни седиментният материал се задържа в тази зона и не навлиза в зоната на отлагане (конуса на р. Рибнишка), която е трудно да бъде подробно характеризирана, найвече поради интензивната антропогенна намеса и разчистването на съвременните отложения. На места в тази зона се наблюдават само хаотично разпръснати блокове и валуни.

След предварителна оценка на опасността, водосбора на р. Рибнишка може да бъде определен като потенциално опасен за развитието на кално-каменни потоци и дебритни прииждания, които се активизират при екстремно количество на валежите. Необходимо е да бъдат проведени допълнителни изследвания за изясняване на количествата на валежите, които биха довели до задвижването им, установяване на повторя- 


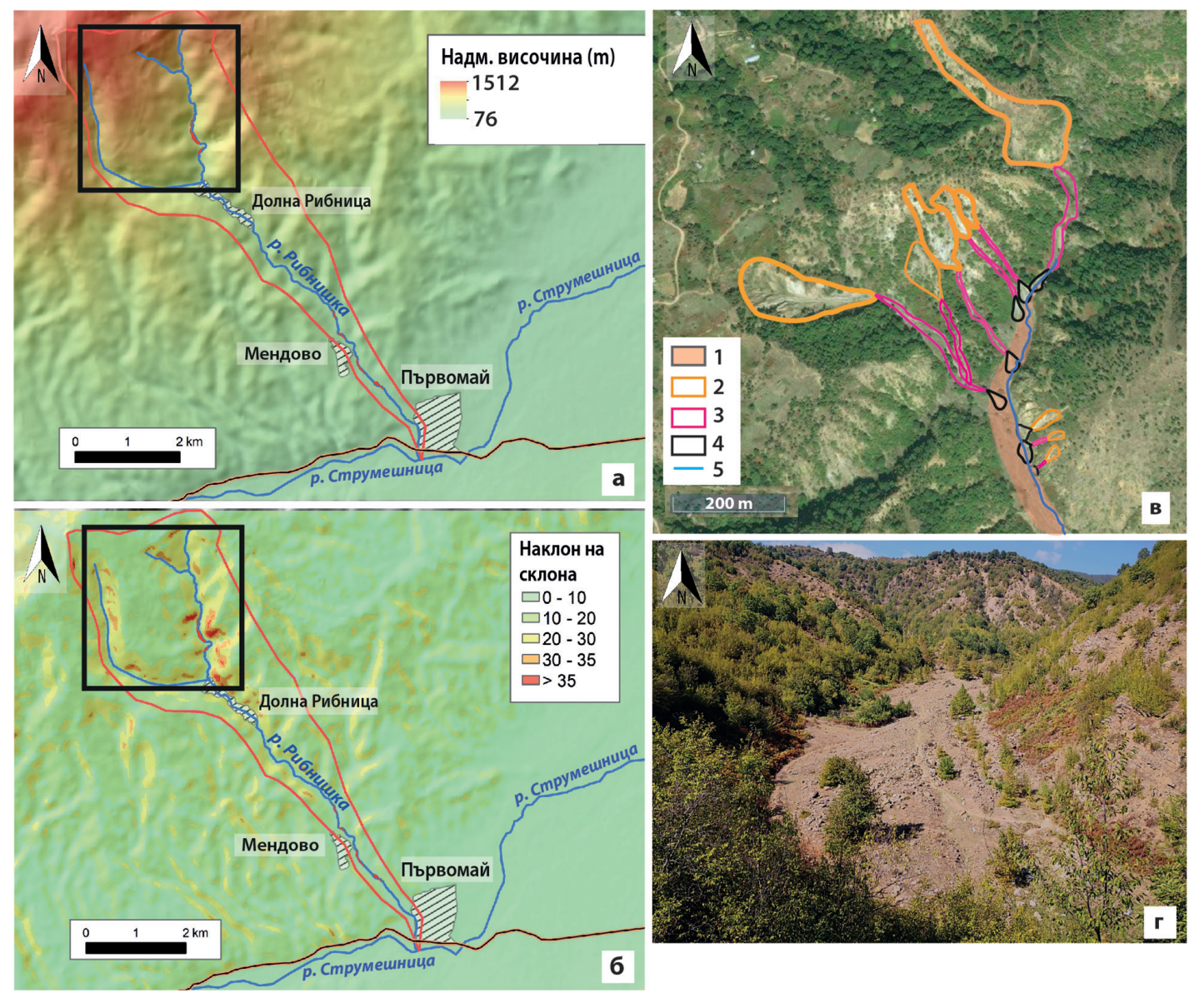

Фиг. 1. $a$ - цифров модел на релефа (30 m, ASTER DEM V3, 2018) с очертана зоната на подхранване (в черно); $\sigma$ - карта с наклона на склоновете; в - зона на подхранване във водосбора на р. Рибнишка. Върху аерофото изображение са очертани: 1 - холоценски алувиални отложения, запълващи речната долина, 2 - подхранващи ерозионни структури, 3 - трансферна зона, 4 - малки по площ съвременни отложения от кално-каменни потоци; г - панорамен изглед към част от зоната на подхранване, в която се осъществява натрупване на седиментен материал от склоновете и по-малките поройни водосбори.

емост на процесите, както и да бъде направен подробен анализ на подхранващата зона на водосбора и да бъде изчислен обемът седиментен материал, който се натрупва в зоната. Получените резултати биха могли да се използват при съставянето на планове за управление на риска и при изготвянето на мерки за превенция.

Благодарности: Настоящото изследване е проведено във връзка с изпълнението на Национална научна програма (ННП) „Опазване на околната среда и намаляване на риска от неблагоприятни явления и природни бедствия“, одобрена с Решение на МС № 577/17.08.2018 г. и финансирана от МОН (Споразумение № Д01363/17.12.2020).

\section{Литература References}

Horton, R. E. 1932. Drainage-basin characteristics. - Trans. Am. Geophys. Union., 13, 350-361.
Kean, J. W., S. W. McCoy, G. E. Tucker, D. M. Staley, J. A. Coe. 2013. Runoff-generated debris flows: Observations and modeling of surge initiation, magnitude, and frequency. - J. Geophys. Res. Earth Surface, 118, 2190-2207; https://doi.org/10.1002/jgrf. 20148.

Klimov, I., A. Marinova, R. Marinova, I. Petrov, P. Milovanov, E. Ilieva. 2004. Geological Map of Bulgaria, Scale 1:50 000. Map Sheets K-34-94- $\Gamma$ (Makrievo), K-34-95-B (Petrich), K-34-106-Б, K-34-107-A (Belasitsa). Sofia, Ministry of Environment and Water, Bulgarian Geological Survey.

Melton, M. 1965. The geomorphic and palaeoclimatic significance of alluvial deposits in Southern Arizona. - J. Geol., $73,1-38$.

ASTER Global Digital Elevation Model V003. 2018. Distributed by NASA EOSDIS Land Processes DAAC; https:// doi.org/10.5067/ASTER/ASTGTM.003.

Panov, P. 2000. Ukrotenite Poroi v Bulgaria. Sofia, Astra R, 291 p. (in Bulgarian).

Pike, R. J., S. E. Wilson. 1971. Elevation-relief ratio, hypsometric integral and geomorphic area altitude analysis. Geol. Soc. Am. Bull., 82, 1079-1084.

Wilford, D. J, M. E. Sakals, J. L. Innes, R. C. Sidle, W. A. Bergerud. 2004. Recognition of debris flow, debris flood and flood hazard through watershed morphometrics. Landslides, 1, 61-66. 